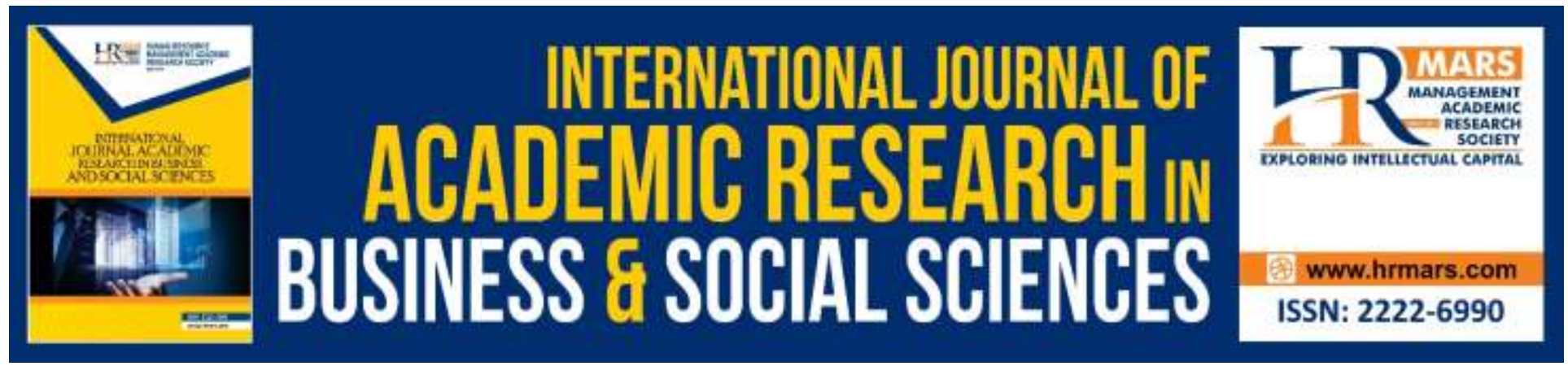

\title{
In the Pursuit of Happiness: The Role of Personality
}

\section{Ellen Chung, Vloreen Nity Mathew \& Geetha Subramaniam}

To Link this Article: http://dx.doi.org/10.6007/IJARBSS/v9-i11/6512

DOI: 10.6007/IJARBSS/v9-i11/6512

Received: 12 Oct 2019, Revised: 20 Oct 2019, Accepted: 30 Oct 2019

Published Online: 04 Nov 2019

In-Text Citation: (Chung, Mathew, \& Subramaniam, 2019)

To Cite this Article: Chung, E., Mathew, V. N., \& Subramaniam, G. (2019). In The Pursuit of Happiness: The Role of Personality. International Journal of Academic in Research Business and Social Sciences, 9(11), 10-19.

\section{Copyright: (C) 2019 The Author(s)}

Published by Human Resource Management Academic Research Society (www.hrmars.com)

This article is published under the Creative Commons Attribution (CC BY 4.0) license. Anyone may reproduce, distribute, translate and create derivative works of this article (for both commercial and non-commercial purposes), subject to full attribution to the original publication and authors. The full terms of this license may be seen at: http://creativecommons.org/licences/by/4.0/legalcode

Vol. 9, No. 11, 2019, Pg. 10 - 19

Full Terms \& Conditions of access and use can be found at http://hrmars.com/index.php/pages/detail/publication-ethics 


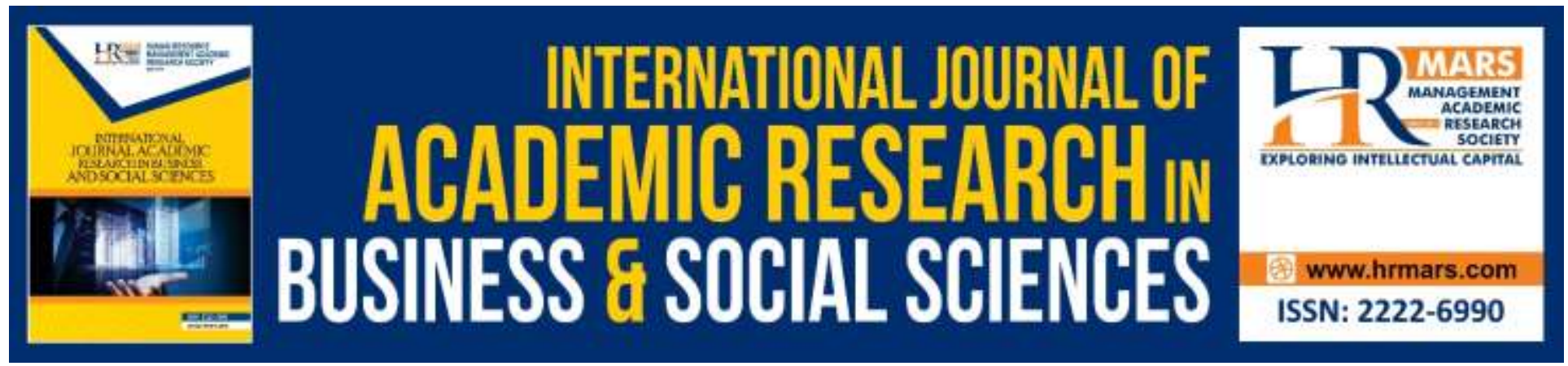

\title{
In the Pursuit of Happiness: The Role of Personality
}

\author{
Ellen Chung ${ }^{1}$, Vloreen Nity Mathew ${ }^{1} \&$ Geetha Subramaniam ${ }^{2}$ \\ ${ }^{1}$ Faculty of Business and Management, Universiti Teknologi MARA Cawangan Sarawak \\ Jalan Meranek 94300 Kota Samarahan Sarawak, Malaysia, Faculty of Business and \\ Management, Universiti Teknologi MARA, 40450 Shah Alam, Selangor, Malaysia \\ Email: ${ }^{1}$ ellencsm@uitm.edu.my
}

\begin{abstract}
Happiness and personality are closely related, like hand in glove. The aim of this study was to investigate the relationship between personality traits and happiness among undergraduates in Malaysia. Using a convenient sampling method, 130 students of five academic programs from Universiti Teknologi MARA, Malaysia completed the Oxford Happiness Questionnaire (OHQ) and NEO Five Factor Inventory (NEO-FFI). Correlation analysis, multiple regression and ANOVA were used to analyse the data. Results showed that happiness scores were positively and significantly correlated $(P<0.001)$ with those on Openness to experience $(r=0.243)$, Conscientiousness $(r=$ $0.609)$, Extraversion $(r=0.446)$, Agreeableness $(r=0.391)$, but were negatively correlated with Neuroticism ( $r=-0.166, P>0.05$ ). Openness to experience, Conscientiousness, Extraversion, Agreeableness and Neuroticism accounted for $48.2 \%$ of variance in predicting happiness. ANOVA results also showed that there was a statistically significant difference in happiness among respondents with different levels of Conscientiousness, Extraversion, and Openness to experience. University Student Affair and Academic Affair Departments of the university should organise initiatives that could identify students' personality traits as this has a bearing on their happiness and hence their performance. Relevant activities need to be organised to enhance students' well-being. This is among the first papers that investigates the relationship between happiness and personality among non-medical undergraduates in Malaysia using OHQ and NEO$\mathrm{FFI}$.
\end{abstract}

Keywords: Happiness, Personality, Openness to Experience, Conscientiousness, Extraversion, Agreeableness, Neuroticism

\section{Introduction}

In psychology, happiness is a mental or emotional state of well-being which can be defined by, among others, positive or pleasant emotions' ranging from contentment to intense joy. Overall, happy people respond positively to events and conditions, have lower stress level and stronger immune system (Lyubomirsky, King \& Diener, 2005). Happy people tend to be more helpful, creative, pro-social, charitable, altruistic, and healthier (Diener \& Dean, 2007). Steptoe and 
Wardle (2011) found that happy people are at reduced risk of dying over the five- year period of their study and the happiest people had a 35\% lower risk of death than the least happy person. Studies into personality and happiness abound in the literature in the 1980s through to 1990s in the Western context such as in UK (Argyle \& Lu, 1990; Furnham \& Brewin, 1990; Lu \& Argyle 1991), in Australia (eg. Brebner, Donaldson, Kirby \& Ward, 1990) and comparative study in UK, US, Australia and Canada (eg. Francis, Brown, Lester \& Philipchalk, 1998).

In Malaysia, it was not until quite recently Malaysia has shown some studies in this field (eg. AlNaggar et al., 2010; Boo, Yen and Lim, 2016). However, there is still limited literature in the context of university students in Malaysia, especially among non-medical students. This rising rate of suicide is a grave concern among the society and studies claim that suicidal thoughts stem from depression, mental health and general unhappiness. While this is not a study to assess psychological and mental health, it aims to identify the level of happiness among the undergraduates and to investigate the relationship between personality traits and happiness.

Also, though past studies have correlated lower life satisfaction with poorer mental health, life satisfaction, and loneliness, Swami et al. (2007) showed that life dissatisfaction, loneliness and depression were not significantly related for 172 medical students in Malaysia. This survey was administered in English and developed and validated in the United States, so may not effectively assess wellbeing as conceptualized in Malaysia.

\section{Literature Review}

\section{Happiness Defined}

Researchers agree that happiness constitutes three main interrelated components namely positive effect, absence of negative effect, and satisfaction with life as a whole (Pishva, Ghalehban, Moradi \& Hoseini, 2011). Happiness is clearly a positive feeling where it causes satisfaction or an expectation that is met. Factors contributing to happiness vary among individuals. Lane (2017) identified that having a positive educational achievement with a strong financial status as determinants to happiness and stated that economic behavior of an individual is related to happiness. The happiness dimensions are further researched and more dimensions have been identified. Among others, are relationship with others, respect towards others, financial status (Jaafar, et al., 2012), work achievements, career achievements (Goldsmith, 2016), relationship with friends and families, self-actualization and freedom and recreation (Hosu \& Fabiola, 2015). In another happiness study by Dean \& Gibbs (2015), a list of self-made happiness definitions were obtained from students. The results revealed that university students define happiness by being content, enjoying life, having supportive friends and family, having positive state of mind, having a stress free life, achieving a balanced life and having confidence.

\section{Oxford Happiness Questionnaire}

In the late 1980's, the Oxford Happiness Questionnaire (OHQ) was introduced for in-house use by the Department of Experimental Psychology of the University of Oxford. In much later years, the Oxford Happiness Index was derived from OHQ. The compact OHQ which is used in this study 
consists of 29 items which respondents answered in a uniform six point Likert scale to measure subjective well-being (SWB) or happiness. To date, the instrument has been employed crossculturally in happiness studies.

\section{Personality}

People who have a high degree of conscientiousness are reliable and prompt. Traits include being organized, methodical and thorough. Agreeable individuals are friendly, cooperative, and compassionate. People with low agreeableness may be more distant. Traits include being kind, affectionate, and sympathetic. Neuroticism is also sometimes called Emotional Stability. This dimension relates to one's emotional stability and degree of negative emotions. People that score high on neuroticism often experience emotional instability and negative emotions. Traits include being moody and tense. People who are open to experience like to learn new things and enjoy new experiences usually score high in openness to experience. Openness includes traits like being insightful and imaginative and having a wide variety of interests. Extraversion includes the traits of energetic, talkative, and assertive. Extraverts get their energy from interacting with others, while introverts get their energy from within themselves (McCrae \& John, 1992).

\section{Personality and Happiness}

Does different personality trait affect happiness? Is a person with specific personality trait happier than others? Which personality trait is the happiest? These questions have been addressed by past research. The big-five personality structure has been used extensively in measuring the relationship between personality and happiness construct. The big-five categories are extraversion, agreeableness, neuroticism, conscientiousness and openness to experience. Each is measured by the high and low extreme. Agbo \& Ngwu (2017) assessed the moderating roles of personality in aversion to happiness and the experience of happiness among university students in Nigeria. Past research discussion elaborates the big-five personality traits. An individual who scores high in extraversion are commonly known to be someone who is always positive, cheerful, bubbly and full of excitement. On the other end, the lower score in extraversion is the opposite. McCrae \& John (1992) explains agreeableness as something which signifies the tendency to accommodate others and being supportive. The people with high score on agreeableness will find happiness in getting involved in social work. The third trait is neuroticism, a more of negative emotion as it measures the consistency to experience negative emotions. The higher the neuroticism, the more likely the person will experience mood swings, worry, anxiousness and fearfulness. Improper control of emotion for someone with this personality may affect happiness. The next trait is conscientiousness which represents someone with high self-control, organized, stick on plans and prioritize tasks. A person with high score on conscientiousness love social arts. Last but not least, openness to experience. Openness to experience puts forth the emphasis on tendency to try new ideas and risks.

\section{Method}

A set of questionnaire which consists of OHQ (Hills \& Argyle, 2002) and NEO-FFI (Costa and McCrae, 1989) which measures the five basic dimensions of personality were used. There were 29 items which measured happiness on a scale ranging from 1 to 6 , with 1 being "strongly 
disagree" and 6 being "strongly agree". There were also six items to measure each of the five personality traits namely Conscientiousness, Agreeableness, Neuroticism, Openness to experience, and Extraversion (CANOE). The response scale ranged as 1 being "not at all" to 4 being "very much so". Data was collected in June 2019 using convenient sampling at one of the branches of Universiti Teknologi MARA Malaysia. A total of 143 sets of questionnaire were returned. After checking for completeness of these questionnaires, 13 were discarded leaving 130 usable sets for further analysis. Data was analysed using Statistical Package for Social Sciences (SPSS). Reliability analysis for $\mathrm{OHQ}$ was 0.89 , while for personality dimensions were between 0.69 to 0.82 . Further tests such as correlation analysis, multiple regression and ANOVA were carried out.

\section{Findings and Discussions}

Out of the 130 respondents, $85 \%$ were females, and $15 \%$ were male. The respondents were between the ages of 18 and 25 years old, from Bachelor program majoring in Marketing (5\%); Finance, (19\%); Office System (25\%); Applied Science (15\%), and Diploma in Hotel Management, (36\%) About half of them had their latest Cumulative Grade Point Average (CGPA) of between 2.50 to 2.99. Almost one out of every four of them was the eldest child in the family while one in every five were the youngest in the family. More than half of them were Malays. Most of them, (367\%) had less than RM200 per month pocket money. Slightly more than one third of the respondents were from Sarawak. There was a disturbing finding among this group of students whereby they only had an average of 6.5 hours of sleep a day. However, they spent up to 9.5 hours a day on their electronic gadgets such as smart phones, tablets and computers. This lack of sleep phenomena can be observed with students looking tired and the verge of dozing off during 8am lectures.

The mean score for the 29 items of OHQ was 122.62. The item with the highest mean score was "I find beauty in some things", while the item "There is no gap between what I would like to do and what I have done" has the lowest score. When level of happiness was examined, results showed that $33.8 \%$ of respondents had medium level of happiness, $66.2 \%$ had high level of happiness. Medium level of happiness has a total score of between 59 to 116, while high level of happiness had total scores of between 117 and 174 .

Descriptive analyses were carried out to investigate who were the happier lot among this group of respondents as opposed to the least happy. Females perceived to be happier with mean score of 123.19 compared to males $(m=119.16)$. The youngest in the family admitted to be the happiest $(m=125.32)$ as opposed to the only child in the family $(m=115.67)$. Money can't buy happiness rings true in this study as respondents with monthly pocket money of RM 800 and above recorded lowest level of happiness $(m=113.67)$ compared to those with less pocket money. Respondents with different levels of academic achievements measured using CGPA of 3.00 to 3.49 perceived higher level of happiness $(m=124.53)$ compared to other groups, especially those of CGPA between 2.01 to 2.49 ( $\mathrm{m}=118.13)$. Those with the best results are not necessarily the happiest, neither are those with bad results the least happy. The Melanau ethnic group recorded 
happiness level higher than average $(m=130.63)$, while Dayaks perceived the lowest level of happiness $(m=120.53)$.

However, further T-test and ANOVA results showed that there was no evidence of statistically significant difference in terms of happiness between gender with $F$ of 0.461 , position in the family, $F=0.667$, monthly pocket money $F=0.489$, different academic results with $F$ of 0.502 , ethnicity with $F=1.063$, all with $p>0.05$.

The five personality traits were divided into three categories of low, moderate and high by transforming the total scores to three different intervals. The results showed that the respondents only had moderate level to high level of the various personality traits. 60 percent of the respondents had moderate level of Conscientiousness, 72 percent of them show high Agreeableness, ten percent reported to be highly Neurotic, almost half of the respondents had moderate level of Openness and extroversion.

Correlation analysis in Table 1 showed that happiness scores were correlated with those on Conscientiousness ( $r=.609)$, Agreeableness $(r=.391)$, Neuroticism $(r=-.166)$, Openness to experience $(r=.243)$, Extroversion $(r=.446)$. All correlations between scores on the subscales of the two measures were significant $(p<.001)$, except for Neuroticism $(p>0.05)$.

Table 1. Correlation between five personality traits and Happiness

\begin{tabular}{lccccc}
\hline Variables & 1 & 2 & 3 & 4 & 5 \\
\hline Conscientiousness & - & & & & \\
Agreeableness & $.391^{* *}$ & - & & & \\
Neuroticism & -.134 & -.055 & - & & \\
Openness to Experience & .104 & $.262^{* *}$ & $.326^{* *}$ & - & \\
Extroversion & $.294^{* *}$ & $.403^{* *}$ & .083 & $.405^{* *}$ & - \\
Total happiness & $.609^{* *}$ & $.391^{* *}$ & -.166 & $.243^{* *}$ & $.446^{* *}$ \\
\hline
\end{tabular}

**. Correlation is significant at the 0.01 level (2-tailed).

Multiple linear regression was employed to find out which personality trait provided the best predictive validity for happiness. The results in Table 2 showed that the five personality traits accounted for 48 percent of the happiness among the respondents. ANOVA showed that Conscientiousness is the strongest and statistically significant predictor of happiness $(\beta=0.478$, $t(129)=6.65, p<0.05)$, Agreeableness is weakest and non-significant predictor of happiness ( $\beta$ $=0.064, p>0.05)$, Neuroticism on the other hand is negative but a significant predictor of happiness $(\beta=-0.161, p<0.05)$, this means an increase in neuroticism leads to reduced happiness. Openness to experience is a predictor of happiness, but it is not significant $(\beta=0.133$, $p>0.082)$. Finally, Extroversion is also a significant predictor of happiness $(\beta=0.239, p<0.002)$. Table 2. Multiple regression analysis 
INTERNATIONAL JOURNAL OF ACADEMIC RESEARCH IN BUSINESS AND SOCIAL SCIENCES

Vol. 9, No. 11, November, 2019, E-ISSN: 2222-6990 ㄷ 2019 HRMARS

\section{Model Summary}

\begin{tabular}{l|l|l|l|l}
\hline Model & $R$ & R Square & $\begin{array}{l}\text { Adjusted R } \\
\text { Square }\end{array}$ & Std. Error of the Estimate \\
\hline 1 & $.694^{\mathrm{a}}$ & .482 & .461 & 11.044 \\
\hline
\end{tabular}

a. Predictors: (Constant), Extroversion, Neuroticism, Conscientiousness, Agreeableness, Openness

\begin{tabular}{|c|c|c|c|c|c|c|}
\hline \multicolumn{7}{|c|}{ Anova ${ }^{a}$} \\
\hline Model & & $\begin{array}{l}\text { Sum of } \\
\text { Squares }\end{array}$ & $d f$ & $\begin{array}{l}\text { Mean } \\
\text { Square }\end{array}$ & $\mathrm{F}$ & Sig. \\
\hline \multirow[t]{3}{*}{1} & Regression & $\begin{array}{l}14071.19 \\
9\end{array}$ & 5 & 2814.240 & 23.074 & $.000^{b}$ \\
\hline & Residual & $\begin{array}{l}15124.00 \\
1\end{array}$ & 124 & 121.968 & & \\
\hline & Total & $\begin{array}{l}29195.20 \\
0\end{array}$ & 129 & & & \\
\hline
\end{tabular}

a. Dependent Variable: Total happiness scores

b. Predictors: (Constant), Extroversion, Neuroticism, Conscientiousness, Agreeableness, Openness

\section{Coefficients $^{\mathrm{a}}$}

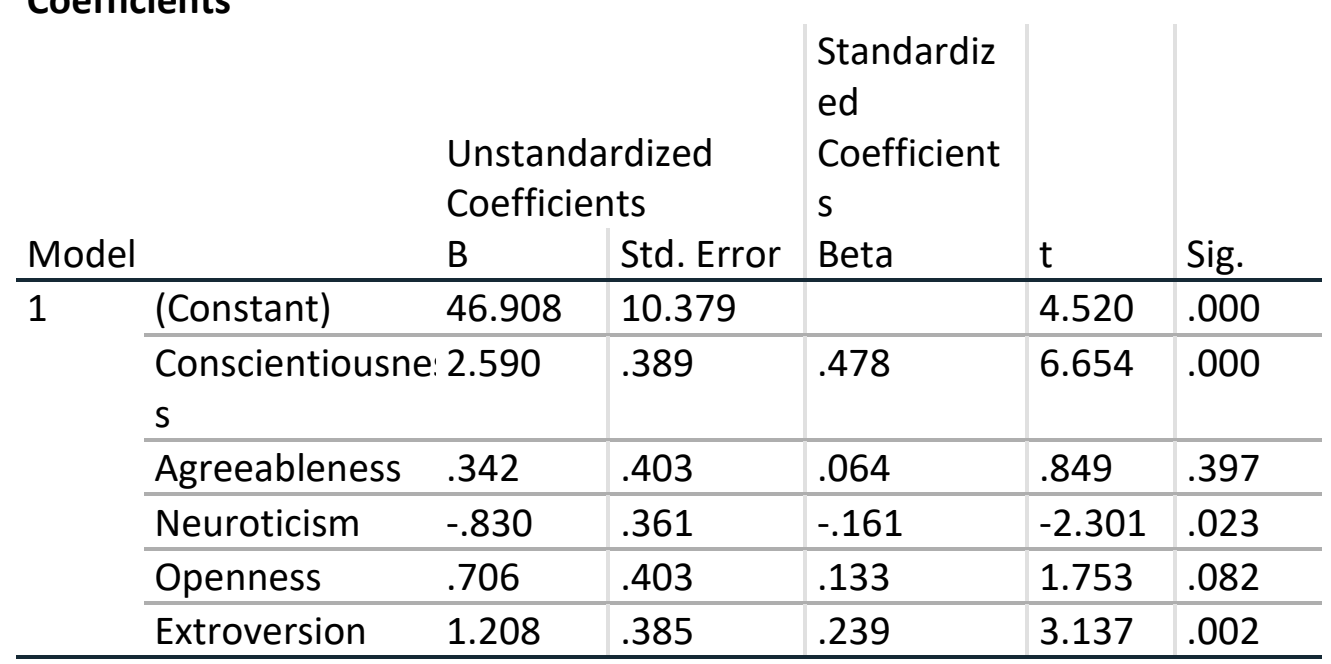

a. Dependent Variable: Total happiness scores

The study examined the predictive power of big five personality traits on happiness. The results revealed that personality traits significantly affected happiness. Specifically, Conscientious and Extraverted individuals express a high level happiness (Tan, Low and Vaipude, 2018). On the other hand, Neuroticism influence happiness in a negative way. These suggest that personality traits are an important determinant of happiness. These findings are consistent with previous studies (eg.; DeNeve and Cooper, 1998; Hayes and Joseph, 2003). This study also revealed that one in 
every two respondents reported to have a moderate level of happiness while the rest had high level of happiness. This is considered to be an encouraging sign showing that their well-being is in a good state.

Analysis also showed that Conscientiousness is the strongest and significant predictor of happiness, followed by Extroversion, and Neuroticism, which is a negative predictor of happiness. Neuroticism is also negatively correlated to CGPA. Neurotic students need to be observed as an increase in Neuroticism could lead to a decrease in happiness and overall well-being. If left unattended can lead to depression. To this end, it is suggested that the Student Affairs Department through its Counselling Unit should come up with a program to identify students who tend to be neurotic as an intervention as it is important to enhance their happiness. Although there were only 10 percent of the respondents in this study who reported high level of Neuroticism, intervention is crucial to prevent unwanted events such as attempted suicide.

\section{Conclusion}

This study aimed to measure the level of happiness among non-medical undergraduates at a public university in Malaysia using the Oxford Happiness Questionnaire (OHQ) and NEO Five Factor Inventory (NEO-FFI). Some major findings from this study reveal that firstly, using OHQ, majority (66\%) of the undergraduates have high level of happiness, even though they "find beauty in some things only".

Secondly, in measuring various personality traits, respondents only had moderate level to high level of the various personality traits namely Conscientiousness, (60\%) Agreeableness (72\%), Neurotic (10\%) and Openness and Extroversion (50\%). And only, Conscientiousness, Neuroticism and Extroversion were statistically significant in predicting undergraduates' happiness.

Thirdly, female students and those who are the youngest in the family, with pocket money less than RM800, and CGPA of 3.00 to 3.49, being a Melanau are the happiest group; although there is no statistically significant difference between them.

Finally, it was found that personality traits significantly affect happiness and the most significant predictive power is Conscientious and Extroversion, while Neuroticism influences happiness in a negative way.

These suggest that personality traits are important determinants of happiness. Students who are hardworking, focussed, organized, methodical and thorough tend to be more happy with their aim of studying and the results they obtain. They are also more open and agreeable to what the lecturers' and peers' say, and very cooperative and able to adapt to the "new student environment". Extroverts or students who are more friendly and are able to work in teams are also happier compared to reserved students who prefer to work alone. While neuroticism is a new and worrying issue which is affecting the students due to external and internal pressure. 
These findings will be useful to the management of the university and the university's students' affairs unit which can be more aware of providing an eco-friendly environment for the undergraduates. More outbound programmes and retreats which inculcate team work and togetherness among students can help the students, especially those who stay in hostel away from their families. Hopefully this will avoid suicide issues among undergraduate students which has become quite rampant in the last 10 years.

Future studies should be carried out in order to identify the circumstances which contribute to their Neuroticism. Since personality is formed by both nature and nurture, the University management could organise activities for the targeted groups of students, providing advice to deal with neurotic thoughts. Academic advisors who are appointed among lecturers could also attend to these students to provide assistance to deal effectively with these kind of thoughts. If this is dealt with properly, neurotic thoughts could be reduced and overall well-being of students could be improved.

Happiness affects performance and this in turn has a great impact on the quality of human capital development.

\section{Acknowledgement}

The authors wish to express their gratitude to the respondents of the research for their time and effort in completing the questionnaire. This research was a self-funded project by the researchers.

\section{References}

Agbo, A. A., \& Ngwu, C. N. (2017). Averson to happiness and the experience of happiness: The moderating roles of personality. Personality and Individual Differences, 227- 231.

Al_naggar, R., Al-Jashamy, K. A., Yun, L/w., Isa, Z. M., Alsaror, M. I., and Al-Naggar, A. A. (2010). Perceptions and Opinion of Happiness Among University Students in a Malaysian University ASEAN Journal of Psychiatry, 11 (2) 1-8.

Argyle, M., \& Lu, L. (1990). The happiness of extravert. Personality and Individual Differences, 11, 1011-1-17.

Boo, M. C., Yen, S. H., Lim, H. E. (2016). A Noted on Happiness and life satisfaction in Malaysia. Malaysian Journal of Economic Studies (53(2): 261-277.

Brebner, J., Donaldson, J., Kirby, N., \& Ward, L. (1995). Relationships between happiness and personality. Personality and Individual Differences, 19, 251-258.

Costa, P. T., \& McCrae, R. R. (1989). The NEO-PI/NEO-FFI manual supplement. Odessa, FL.: Psychological Assessment Resources.

Dean, A., Gibbs, P. (2015) Student satisfaction or happiness? A preliminary rethink of what is important in the student experience, Quality Assurance in Education, 23(1), 5-19.

DeNeve, K. M. \& Copper, H. (1998). The happy personality: A meta-analysis of 137 Personality Traits and subjective well-being. Psychological Bulletin, 124 (4), 197-229. 
Diener, R. B. \& Dean, B. (2007). Positive Psychology Coaching. Putting the science of happiness to work for your clients. New Jersey: John Wiley and Sons, Inc

Francis, L. J., Brown, L. B, Lester, D., \& Philipchalk, R. (1998). Happiness as stable extraversion: a cross-cultural examination of the reliability and validity of the Oxford Happiness Inventory among students in UK, USA, Australia and Canada. Personality and Individual Differences, 24, 167-171.

Furnham, A., \& Brewin, C. R. (1990). Personality and happiness. Personality and Individual Differences, 11, 1093-1096. Hayes, N \& Jospeh, S (2003). Big 5 correlates of three measures of subjective well-being. Personality and Individual Differences. 34(4), 723-727

Hills, P., \& Argyle, M. (2002). The Oxford Happiness Questionnaire: a compact scale for the measurement of psychological well-being. Personality and Individual Differences. 33, 10791082.

Jaafar, J. L., Idris, M. A., Ismuni, J., Fei, Y., Jaafar, S., Ahmad, Z., Suprayogi, Y. (2012). The Sources of Happiness to the Malaysians and Indonesians: Data from a Smaller Nation. Procedia Social and Behavioral Sciences, 65, 549-556.

Kashdan, T., B. (2004). The assessment of subjective well-being (issues raised by the Oxford Happiness Questionnaire). Personality and Individual Differences. 36, 1225-1232.

Lane, T. (2017). How does happiness relate to economic behavior? Journal of Behavioral and Experimental Economics 68, 62-78.

Lu, L., \& Argyle, M. (1991). Happiness and cooperation. Personality and Individual Difference, 12, 1019-1030

Lyubomirsky, S., King, L., \& Diner, E. (2005). The benefits of frequent positive affect; does happiness lead to success? Psychology Bulletin, 131, 803- 855

McCrae, R. R., \& John, O. P. (1992). An introduction to the five-factor model and its applications. Journal of Personality, 60, 175-215.

Pishva, N., Ghalehban, M., Moradi, A., \& Hoesini, L. (2011). Personality and Happiness. Procedia - Social and Behavioral Sciences 30, 429-432.

Steptoe. A, \& Wardle. J, (2011). Positive affect measured using ecological momentary assessment and survival in older men and women. Journal Proceddings of the National Academy of Science, 108, 18244-18248

Tan, C. S., Low, S. L., Viapude, G. N. (2018) Extraversion and happiness: The mediating role of social support and hope. Psychology Journal 7(3), 133-143. 